\title{
An audit of research activity among trainee psychiatrists
}

\author{
Ola Junaid, Senior Registrar, and RaChel Daly, Senior House Officer, \\ Professorial Unit, Mapperley Hospital, Nottingham NG3 6AA
}

Productivity in research is now an almost mandatory requirement for trainee psychiatrists. There is an increasing awareness among psychiatric trainees of the necessity to participate in and indeed publish research in order to ensure career progression (Junaid \& Staines, 1990). This paper describes the research activity of psychiatrists in the training grades, during the year October 1988 to September 1989.

\section{The study}

The British Journal of Psychiatry, the Psychiatric Bulletin and the Abstracts of Proceedings of Meetings of the Royal College of Psychiatrists (supplement 2 to the Psychiatric Bulletin) were used as sources of publications with a research component.

Information was collected from the publications, medical personnel officers in the authors' hospitals and by personal communication. The grade of the author, the type of publication, the number of authors per paper, the type of rotation (i.e. teaching hospital or non-teaching hospital) and the area of the country in which the research was carried out were subjected to analysis.

Scotland, Wales, Midlands, North East, North West and South Western correspond to the College Divisions. Oxford represents Oxford Regional Health Authority. East Anglia represents East Anglia Regional Health Authority. London represents the four Thames regions.

\section{Findings}

In the 12 journals during the audit, 45 trainees contributed to $16 \%$ of the 253 original research articles and case reports. Of the trainee contributions, $60 \%$ were case reports, $40 \%$ were original research articles; $16 \%$ were single author publi cations. Senior house officers produced $2 \%$, registrars $62 \%$ and senior registrars/lecturers $36 \%$ of the publications.

Four centres, the Maudsley, Prestwich Hospital Manchester, the Royal Liverpool, and the Royal Edinburgh accounted for $35 \%$ of the publications. Only one publication originated in a non-teaching hospital.

Of the 157 review articles and original research papers in the Psychiatric Bulletin, 22\% involved contributions by trainees. Review articles accounted for $63 \%$ of the trainee contribution. Only $37 \%$ were original research papers.

Of the publications, $57 \%$ were by single authors. Of the trainees, $55 \%$ were of senior registrar or lecturer grade, and $45 \%$ were registrars.

Six per cent of the publications were produced by trainees in non-teaching hospitals.

There were 243 entries in the Abstracts. Trainees contributed to $32 \%$ of the total. Of the trainees, $85 \%$ were either senior registrars or lecturers, $15 \%$ were registrars. Of the contributions, $5 \%$ were produced by trainees from non-teaching hospitals.

TABLE I

Published research by psychiatric trainees - October 1988 to September 1989

\begin{tabular}{lrrrrcc}
\hline Area & $\begin{array}{r}\text { I } \\
\%\end{array}$ & $\begin{array}{l}\text { II } \\
\%\end{array}$ & $\begin{array}{l}\text { III } \\
\%\end{array}$ & $\begin{array}{l}\text { IV } \\
\%\end{array}$ & $\begin{array}{c}\text { Number of } \\
\text { teaching hospitals }\end{array}$ & $\begin{array}{c}\% \text { Research per } \\
\text { teaching hospitals }\end{array}$ \\
\hline London & 26 & 40 & 36 & 35 & 8 & 4.3 \\
Northwest & 21 & 14 & 16 & 17 & 2 & 8.5 \\
Northern & 10 & 9 & 15 & 12 & 2 & 6.0 \\
Midlands & 10 & 20 & 5 & 11 & 4 & 7.8 \\
Oxford & 8 & 3 & 10 & 7 & 1 & 7.0 \\
Wales & 3 & 0 & 12 & 7 & 1 & 1.3 \\
Scotland & 13 & 3 & 4 & 5 & 4 & 5.0 \\
South Western & 8 & 9 & 1 & 5 & 1 & 0.0 \\
East Anglia & 0 & 0 & 0 & 0 & 1 & 0 \\
\hline
\end{tabular}

Key: I British Journal of Psychiatry

II Psychiatric Bulletin

III Abstracts of Proceedings of Meetings of the Royal College of Psychiatrists

IV Total 
Research by trainees is predominantly undertaken in teaching hospitals. Only $3 \%$ of all the research came from trainees in non-teaching hospitals.

Table I provides an indicator of regional productivity. The three sources of publications are combined to give information on total production expressed as a percentage by each of the areas. Expressing research productivity per unit teaching hospital indicates that the teaching hospitals in the North West are the most productive. Each teaching hospital producing $8.5 \%$ of the research published during the study. The teaching hospital in East Anglia was the least productive.

\section{Comment}

There are certain deficiencies in our methodology. In order to accurately ascertain trends in research productivity a year may be too short a time. The selection of three sources of publications will exclude work published in other journals during the year studied.

Our study shows significant regional variation in research productivity among trainee psychiatrists.

The most productive division is the North West. The least productive division is Scotland. It is most surprising that East Anglia produced no published research in the sources analysed during this audit.

It is not surprising that London with the Maudsley and several teaching hospital based rotations is the most productive area. Of greater interest is the North West Division. This division has two teaching hospitals but has produced an equal amount of research as the Scottish, Welsh and South Western divisions combined with three times as many teaching hospitals. What are the factors contributing to the high level of productivity in the North West?

\section{Conclusion}

There is a wide variation in the production of research by trainees in psychiatry in the United Kingdom. Further work needs to be carried out to identify those factors which encourage trainees to successfully complete research.

\section{Reference}

Junaid, O. \& Staines, J. (1990) Career progression in psychiatry: perceptions and realities. Psychiatric Bulletin, 14, 484-486.

\section{The College Library}

The Library currently receives the following journals. Members are entitled to 50 pages of photocopies each year free of charge. Copies in excess of this number will cost 10 pence per page. Photocopies may be requested in person, by post, telephone or fax (071-245 1231). All photocopying is done within the terms of the current Copyright Act.

Acta Psychiatrica Scandinavica and supplements American Journal of Mental Retardation

American Journal of Orthopsychiatry

American Journal of Psychiatry

Annales Medico-Psychologiques

Annali di Neurologia e Psichiatria

Archives of General Psychiatry

Australian and New Zealand Journal of Psychiatry

Biological Psychiatry

British Journal of General Practice

British Journal of Medical Psychology

British Journal of Psychiatry

British Medical Journal

Bulletin of the Menninger Clinic

Canadian Journal of Psychiatry

Ceskoslovenska Psychiatrie

Comprehensive Psychiatry

Convulsive Therapy

Current Work in the History of Medicine

History of Psychiatry

Howard Journal of Criminal Justice

L'Information Psychiatrique

International Journal of Geriatric Psychiatry

Israel Journal of Psychiatry and Allied Subjects

Journal of Affective Disorders
Journal of the American Academy of Child and Adolescent Psychiatry

Journal of Audiovisual Media in Medicine

Journal of Child Psychology and Psychiatry and Related Disciplines

Journal of Clinical Psychiatry

Journal of the History of the Behavioural Sciences

Journal of Mental Deficiency Research

Journal of Nervous and Mental Disease

Journal of Neuropathology and Psychiatry (Russian)

Journal of Psychosomatic Research

Journal of the Royal College of Physicians of London

Journal of the Royal Society of Medicine

Lancet

Mental Health Nursing

Open Mind

Pavlov Journal of Higher Nervous Activity (Russian)

Psychiatrie Francaise

Psychiatry

Psychiatry Research

Psychological Bulletin

Psychological Medicine

Social Psychiatry

Socijalna Psihijatrija 